\title{
Application of stress susceptibility index and multivariate analysis of tomato (Solanum lycopersicum L.) to identify thermo-tolerant genotypes
}

Archana K. A. ( $\nabla$ treesaarchanavimal@gmail.com )

Kerala Agricultural University

T. Pradeepkumar

Kerala Agricultural University

Pratheesh P Gopinath

Kerala Agricultural University

Santhoshkumar A. V.

Kerala Agricultural University

\section{Research Article}

Keywords: Heat Susceptibility index, Thermo-tolerance, Multivariate analysis, Clustering

Posted Date: April 7th, 2021

DOl: https://doi.org/10.21203/rs.3.rs-341217/v1

License: (c) (i) This work is licensed under a Creative Commons Attribution 4.0 International License.

Read Full License 


\title{
Application of stress susceptibility index and multivariate analysis of tomato (Solanum lycopersicum L.) to identify thermo-tolerant genotypes
}

Archana K. A. ${ }^{1+*}$, T. Pradeepkumar ${ }^{1+}$, Pratheesh P Gopinath ${ }^{2}$, Santhoshkumar A.V. ${ }^{3}$

${ }^{1}$ College of Agriculture, Department of Vegetable Science, Kerala Agricultural University, Vellanikkara, Thrissur- 680656, Kerala, India

${ }^{2}$ College of Agriculture, Department of Agricultural Statistics, Kerala Agricultural University, Vellayani, Trivandrum- 695522, Kerala, India

${ }^{3}$ College of Forestry, Department of Tree Physiology and Breeding, Kerala Agricultural University, Vellanikkara, Thrissur- 680656, Kerala, India

*Corresponding author email: treesaarchanavimal@gmail.com; phone: 9400461303

${ }^{+}$Contributed equally to the work

\begin{abstract}
Climatic parameters have become key mechanisms in controlling crop productivity worldwide. The more frequency of heat waves urges the breeding for thermo-tolerance. The motive of this study was to furnish an accurate and deep understanding on the heat tolerance of reproductive key traits (flowers with exerted stigma, pollen viability, fruits set per cent and number of fruits per cluster), along with earliness (days to first fruit set) and yield traits (average fruit weight, pericarp thickness, number of fruits per plant and yield per plant) in tomato. The study reasoned 35 genotypes employing three no-identical analysis tools, ANOVA of field assessment, stress susceptibility index and multivariate analysis based on genetic diversity. Insights of genetic architecture of the reproductive traits under heat stress might improve our core understanding, and might have applied value. The study substantiated the essence of heat tolerance for the genotypes EC-620395, EC-620401, EC-620406 and EC-620410. Divergence analysis revealed five clusters corresponding to specific characters Therefore on the ground of the investigation new breeding lines and breeding strategies can be implemented under changing environmental conditions with special reference to elevated temperature.
\end{abstract}

Key words: Heat Susceptibility index; Thermo-tolerance; Multivariate analysis; Clustering

\section{Declarations}




\section{Funding}

This project is based on the fund granted from Kerala Agricultural University to Ms. Archana K A for the completion of the $\mathrm{Ph} \mathrm{D}$ work.

\section{Conflicts of interest}

The authors declare no conflicts of interest. The funders had no role in the design of the study, in the collection, analysis and interpretation of the data, in the writing of the manuscript or in the decision to publish the results.

\section{Availability of data and material}

The dataset generated during the current study can be found available in the $\mathrm{Ph} \mathrm{D}$ thesis of Ms Archana K A

\section{Code availability}

Not applicable

\section{Author's contribution}

Conceptualization, methodology, investigation, writing the original draft-1; Statistical analysis-2; Resources, review and editing-3. All authors have read and agreed to the printed version of the manuscript.

\section{Introduction}

Tomato (Solanum lycopersicum L.) occupies an eminent position among the vegetables and its cultivation has roll out globally. The agro-climatic conditions of tropical, subtropical and temperate zones are well suited for tomato (Singh et al. 2014). In traditional agriculture, tomato turns up well in winter months (Ruggieri et al. 2019). During summer months the crop does not grow well due to hostile weather conditions (Singh et al. 2014). With rising zeal for its cultivation, the farmers are aptly looking towards upgraded varieties to meet out higher demands of seasonal dissimilarity (Dhillon et al 2019; Zdravkovic et al. 2013). Course of action to take the edge off yield cutback bringing on heat, encompass the production and use of heat tolerant genotypes, and for this a finer perception of the plant response and adaptations to heat stress is a precondition (Jha et al. 2014). A temperature surpassing $30^{\circ} \mathrm{C}$ weaken various vital physiological processes viz; respiration and transpiration (Stone 2001), pollen production and viability (Camejo et al. 20105), seedling emergence, 
photosynthesis (Xu et al. 2017a) and that eventually result in the substantial yield loss (Adam et al. 2001; Pressman et al. 2002; Barnab et al. 2008; Hedly 2008; Zinn et al. 2010). The most commercial cultivars of tomato in Kerala perform well in the wintertime cultivation. Yet they break down in summertime. Kerala relish the classic tropical climate, where the summer temperature obviously crosses $38^{\circ} \mathrm{C}$ (Alam et al. 2010).

Different strategies, for instance screening and selection of varieties (Zamir 2001; Srivastava et al. 2016) may provide a resource for evolving resistant and relatively resistant genotypes, since stress tolerance is a developmentally regulated state-specific phenomenon. To differentiate the degree of resistance amidst the screened genotypes, Stress Susceptibility Index (SSI) has been proposed (Fisher and Maurer 1978). It is the ratio of genotypic performance under stress and non-stress conditions (Jha et al. 2014). Safeguarding the crop by protected cultivation was in subject of research team in the previous periods (Jha et al. 2014; Singh et al. 2014).

In this manuscript, 35 tomato genotypes were screened for high temperature tolerance inside rainshelter. Analysis was accomplished with field screening and heat susceptibility indexing. The current evaluations at different temperature regimens, pointed out varying degree of resistance. Therefore the genotypes were further studied in multivariate analysis to discern the genetic relationship among them. The joint analysis could be a powerful tool for thermo stable line identification and would play a vital role in future agriculture.

\section{Materials and methods}

The core segment of the current work was the field appraisal of tomato genotypes for tandem season, one summer (from January 2018 to May 2018) and one rainy (July 2018- December 2018) at Vegetable Science Department, College of Agriculture, Vellanikkara, Thrissur at an altitude of $22.25 \mathrm{~m}$ above mean sea level, between $10^{\circ} 31^{\prime} \mathrm{N}$ latitude and $76^{\circ} 13^{\prime} \mathrm{E}$ longitude, with tropical warm humid climate and mean annual rainfall of $2663 \mathrm{~mm}$ (sandy loam soil with $\mathrm{pH}$ 5.7). The investigation material was 35 tomato genotypes, 29 genotypes from NBPGR, New Delhi, Pusa Ruby, 3 IIHR Bangalore varieties (Arka Abha, Arka Saurabh and Arka Alok), and $2 \mathrm{KAU}$ released varieties (Akshaya and Anagha). The genotypes were raised in nursery pro-trays filled with potting mixture red earth, sand and cow dung in the proportion of 2:1:1 for twenty one days and shifted to the rainshelter $(24 \mathrm{~m} \times 16 \mathrm{~m} \times 3.1 \mathrm{~m})$ at spacing of $1 \mathrm{~m} \times 0.5 \mathrm{~m}$ on raised beds $(23 \mathrm{~m} \times 1 \mathrm{~m})$, enveloped with black and white double shaded polythene mulch of 30-micron thickness, with drip irrigation. The configuration of the experiment was Randomized Block Design (RBD) with two replications and ten plants per replication. The plants were hold up on long pole and regularly pruned. Plant protection has been shouldered as per the ad-hoc guidelines of KAU (Estelitta et al. 2016). 


\section{Phenotypic evaluation}

The heat tolerance distinctions assessed were flowers with exerted stigma (\%), pollen viability (\%), fruit set per cent and number of fruits per cluster (number).

Flowers with exerted stigma (\%)

$$
=(\text { no of flowers with exerted stigma |total number of flowers in the cluster) }
$$$$
\times 100
$$

Fruit set per cent

$$
\begin{aligned}
& =(\text { total no of fruits at mature green stage|total no of flowers in the cluster) } \\
& \times 100
\end{aligned}
$$

For pollen viability the pollen grains from flowers that bloom on the very day were spotted in acetocarmine stain and observed under microscope (Abdul-Baki 1992) (Figure 1)

Pollen viability $(\%)=($ no of viable pollen grains $\mid$ total no of pollen grains in the field $) \times 100$

The earliness of the genotypes was recognized from the days to first fruit set. The yield properties of average fruit weight $(\mathrm{g})$, pericarp thickness $(\mathrm{g})$, number of fruits per plant (number) and yield per plant $(\mathrm{g})$ were rated as well. The mean of all quantitative traits mentioned above were subjected to statistical analysis and mean was compared with the help of ANOVA for each character separately at $\mathrm{p}=0.05$ (Fisher 1957).

\section{Heat Susceptibility Index}

To evaluate the heat tolerance of investigated genotypes, the HSI was determined (Fisher and Maurer 1978) for pollen viability, fruit set per cent, average fruit weight and yield per plant as differences in the results obtained for stressed (during summertime) and non-stressed (in the rainy season) by fitting into the equation:

$$
H S I=\frac{\{1-Y h / Y\}}{\{1-X h / X\}}
$$

In the equation,

$Y h=$ Phenotypic means foreach genotype at stressed condition $Y=$ Phenotypic means for each genotype at non - stressed condition

$X h=$ Phenotypic means of all genotypes at stressed condition $X=$ Phenotypic means of all genotypes at non - stressed condition 
A three point scale was used for scoring. The HSI value below 0.5 implies heat tolerance, in the range 0.5 to 1.0 denoted moderate tolerance and exceeding 1.0 hinted the heat susceptibility of the genotype (Singh et al. 2017).

\section{Multivariate cluster analysis}

Multivariate cluster analysis was also employed as a selection standard, for understanding divergence of the investigated genotypes in reference to phenotypic characteristics. Divergence was estimated using Euclidean distance with complete genes attachment to grouping. The genotypes were clustered by Tocher's method (Rao 1952). The analysis was performed implementing and using R package (R version 3.6.3 (2020-0229))

\section{Result and discussion}

The seasonal appraisal delineated notable dissimilarity amidst the genotypes and the differential response of genotypes to unlike weather conditions.

\section{Flowers with exerted stigma (\%)}

Protrusion of style over the anther cone, the most outstanding reaction of uplifted temperature on female reproductive organ, was observed in the current work as well (Table 1 and Figure 2). During summertime the genotype EC-620382 towered (56.9\%), and during the rainy season Arka Abha (36.5\%). Sixteen genotypes displayed additional incidence of stigma protrusion in summertime, and the deviation exceeded 5\%. Ten genotypes viz; EC-164263, EC-164670, EC-165395, EC-165690, EC-521067 B, EC620389, EC-620406, EC-620429, EC-631369 and Arka Abha revealed non-significant difference for flowers with exerted stigma betwixt the seasons. During summer time eleven genotypes and in the course of rainy season evaluation eight genotypes disclosed stigma exertion in excess of 30\%. Six genotypes viz; EC-151568, EC-160885, EC-620382, EC-620427, EC-620429 and Arka Abha wrote down stigma protrusion surpassing $30 \%$ for tandem appraisal. Several definite genotypes principally produce exerted stigma favouring the outcrossing (Driedonks et al. 2018). Under high temperature conditions, thermo-sensitive genotypes communicate different responses of pectin, sugar, expansin and cyclin, causing cell wall remodelling and differential confined cell division and cell enlargement, which govern the length of pistils (Pan et al 2018; Gonzalo et al. 2020). The result of current work was consistent with the previous documents (Giorno et al. 2003; Sato et al. 2006; Din et al. 2015; Saeed et al. 2017; Xu et al. 2017b). 


\section{Pollen viability (\%)}

The temperature during the pollen formation is ample to cause major differences in the pollen viability. The current work noted fifteen genotypes exhibiting more than 5\% difference between the seasons, with excessive pollen viability in the rainy season (Table 1). In both the seasons the genotype EC-165395 towered pollen viability (64.4\% and $65.4 \%$ for summer and rainy season respectively). Two genotypes, EC-165700 and EC-620378, exhibited more pollen viability in the summer season. Two genotypes, EC-620376 and Pusa Ruby, exhibited non significant changes betwixt the season. Continuous exposure of tomato plants to high temperature impart differential accumulation of hexose $V s$ sucrose in developing pollen grains (Paupiere et al. 2014) and delayed tapetum development (Alsamir et al. 2017; Razzaq et al. 2019), thereupon imparting different levels of tolerance. Metabolic alterations in the thermo-tolerant genotypes leads to the proline accumulation, acting as a heat shock protein (Giorno et al. 2003; Sato et al. 2006; Din et al. 2015; Saeed et al. 2017; Xu et al. 2017b). The differential response in the pollen viability of genotypes to high temperature has remarkably been documented (Zamir 2001; Singh et al. 2017; Xu et al. 2017b; Dhillon et al. 2019).

\section{Fruit set per cent}

Stress outcome on the fruit set has more dramatic repercussions on the yield. The current work remarked better fruit set per cent in rainy season for 30 genotypes (Table 1). The maximum fruit set per cent was observed for the genotype EC-620410 (63.8\%) for summer appraisal and for the genotype EC-620406 (67.4\%) for the rainy season appraisal. Five genotypes viz; EC-164263, EC-164563, EC-521067 B, EC-631369 and Pusa Ruby exhibited more fruit set per cent in the summer appraisal. Nine genotypes EC-145057, EC157568, EC-160885, EC-163605, EC-165690, EC-528368, EC-620427, EC-620429 and EC-631379 recorded seasonal variation exceeding 10\%. Five genotypes viz; EC-165395, EC-165690, EC-620401, EC-620406 and EC-620410 wrote down fruit set per cent exceeding $60 \%$ for tandem assessment. The genotypes with virtue of increased levels of ABA expression in the leaves exhibited acceptable fruit set per cent ( $\mathrm{Li}$ et al. 2005; Srivasthava et al. 2016) at normal and stressed environments. Limited fruit set at elevated temperature is for many reasons including exerted stigma (sato et al. 2006; Gonzalo et al. 2020), loss of blossom (Srivasthava et al. 2016) and limiting pollen viability (Xu et al. 2017b; Gonzalo et al. 2020), owing to the alterations in the structure of enzymes (Hameeda et al. 2015; Singh et al. 2015). The outcomes of Adams et al. 2001; Srivasthava et al. 2016; Singh et al. 2017; Tolessa and Heuvelink 2018 also announced the differing fruit set per cent of genotypes for dissimilar weather framework. 


\section{Number of fruits per cluster (number)}

Number of fruits per cluster is viewed as good prediction for fruit retention capacity at elevated temperature. The investigation noted more number of fruits per cluster in the rainy season for 22 genotypes (Table 1). Seven genotypes viz; EC-165395, EC-165690, EC-521067 B, EC-528368, EC-620406, EC-620410 and Pusa Ruby were distinguished with additional increase in the number of fruits per cluster in the summer. Six genotypes exhibited staticity in the number of fruits per cluster, EC-165700, EC-620389, EC-620395, EC620401, Akshaya and Anagha. Tomato is perceived with propensity towards bud drop (Tolessa nd Heuvelink 2018), under developed fruit and flower drop (Panthee et al. 2018) and small parthenocarpic fruits with low flower number and fruit set (Adams et al. 2001) at elevated temperature contributing to shrinking in the number of fruits per cluster. Genotypes exhibiting vegetative heat tolerance, recovers better towards the end of the summer (when the temperature cools), and exhibits upper canopy fruiting (Panthee et al. 2018) maintaining fruit number per cluster. Variability in the number of fruits per cluster and trimming in the number of fruits per cluster in the summer were previously been reported (Alsamir et al. 2018; Panthee et al. 2018; Gonzalo et al. 2020).

\section{Days to first fruit set (number of days)}

Days to first fruit set is cardinal in regulating the earliness of the crop. The appraisal noted similar pattern of earliness in the summer season for 29 genotypes for days to first fruit set (Table 2). During summer assessment the genotype EC-620395 was the earliest (33.2 days) and the genotype EC-620417 was late one (45.8 days). In the course of rainy season the genotype EC-620376 (35.4 days) noted the earliest flowering and the genotype EC-145057 (49.8 days) documented the late flowering. The genotypes EC-521067 B, EC-620376, EC-620406 and EC-620417 wrote down earliness in the rainy season evaluation. Two genotypes, EC-620387 and EC-620410, documented non-significant changes for days to first fruit set for tandem appraisal. Days to first fruit set fabricated a consistent trend (Agele et al. 2002). The high precipitation and relative humidity in the rainy season advocate the production of huge biomass, and the fruiting incline toward the late side (Oladin and Oluwasemire 2018). Late season crop flowering earlier than the rainy season planting was previously been observed (Agele et al. 2002; Oladin and Oluwasemire 2018).

\section{Average fruit weight (g)}


Fruit weight is one chief element that contributes to the yield. The investigation recorded (Table 2) average fruit weight in the extend of $4.2 \mathrm{~g}$ (EC-165700) and $94.2 \mathrm{~g}$ (EC-538153) for summer assessment, and in the radius of $10.9 \mathrm{~g}$ (EC-620376) and $95.3 \mathrm{~g}$ (EC-538153) for the rainy season assessment. There was increased average fruit weight in the rainy season for 25 genotypes. Ten genotypes viz; EC-160885, EC-163605, EC164563, EC-164670, EC-249514, EC-521067 B, EC-620387, EC-620427, EC-631369 and EC-631379 exhibited a difference exceeding $10 \mathrm{~g}$ betwixt the seasons. Seven genotypes disclosed additional fruit weight in the summer appraisal viz; EC-528368, EC-538153, EC-620376, EC-620389, EC-620406, and Arka Saurabh. EC620417, Arka Alok, Anagha and Akshaya noted non-significant change in the average fruit weight in the tandem assessment. Production rate of photosynthates (more in the wet season Panthee et al. 2018) and drymatter partitioning were dynamic, hanging on prevailing weather parameters and propinquity betwixt source and sink (Darawshesh and Bouranis 2006). During the fruit loading remobilization and redistribution of the carbohydrates to fruits is observed from leaves and stem (Ashrafuzzman et al. 2010). Aspects of these relationships in tomato have been described formerly (Darawshesh and Bouranis 2006; Alam et al. 2010; Ashrafuzzman et al. 2010).

\section{Pericarp thickness $(\mathrm{cm})$}

The fruit morphology constitutes reference to robust and stable fruit phenotypes. EC-620406 and EC620429 exhibited maximum pericarp thickness $(0.84 \mathrm{~cm})$ for summertime and EC-620427 exhibited maximum pericarp thickness $(0.86 \mathrm{~cm})$ for rainy season. Thick fruits were observed for twenty one genotypes during summertime. The genotype EC-521067 B exhibited staticity in the pericarp thickness for two seasons $(0.5 \mathrm{~cm})$. The genotype EC-165690 displayed non-significant change for pericarp thickness over the seasons. The alterations in the tissue morphology usually depend on the cell divisions, expansion and cell size along the medio-lateral axis (Musseau et al. 2017). Increased cell divisions in the epidermis, increase the number of pericarp cell layers. Fruit tissue morphology analysis has been documented formerly (Cheniclet et al. 2005; Musseau et al. 2017; Renaudin et al. 2017).

\section{Number of fruits per plant (number)}

Number of fruits per plant envisaged an index of yield prediction in tomato. The work noted 17 genotypes with improved number of fruits per plant in the rainy season assessment (Table 2). Two genotypes, EC-165395 and EC-165690, exhibited exceptionally high number of fruits per plant, and EC-165690 (71.9 and 67.0 for summer and rainy season, respectively) towering both the seasons. Ten genotypes viz; EC-160885, 
EC_164263, EC-165395, EC-165690, EC-249514, EC-620387, EC-620389, EC-620395, EC-631379 and Pusa

Ruby were distinguished with added fruits in the summer assessment. The genotypes EC-163605, EC-164563, EC-538153, EC-620410, EC-620429, EC-631369, Arka Saurabh and Akshaya indicated ecological adaptations for dissimilar weather conditions. Genotypes exhibited independency in the stress responsive mechanism (Sato et al. 2002). Heat stress correlated fruit number trimming, primarily linked with reduced fruit set and pollen viability, (Sato et al. 2002; Zhou et al. 2017; Driedonks et al. 2018), was consistent in this work as well. Heat tolerant genotypes exhibit increased chlorophyll content, higher number of stomata and bigger stomatal pore size (Sato et al. 2002), thereby maintaining substrate carbon conversion about $25 \%$ irrespective of temperature (Panthee et al. 2018). These seasonal and varietal interplay in number of fruits per cluster has been reported by Rajashekar et al. 2006; Alam et al. 2010; Ashrafuzzman et al. 2010; Hossain et al. 2014.

\section{Yield per plant (g)}

Any abiotic stress has a direct impact on the yield of tomato. The work noted a rise in the rainy season yield for 12 genotypes (Table 2). EC-620387 noted significantly higher returns in the summer appraisal. Remaining genotypes exhibited non-significant changes over the seasons. For the genotypes EC-528368, EC620401 and EC-620410 per plant yield dissimilarity was under 20.0g. The escalated expression of ABA in leaves has been reported (Ilker et al. 2011) at super-optimal temperature for heat tolerant types, accomplishing similarity in the yield levels at dissimilar weather. Yield is a complex character (Reddy et al. 2013a), and the components individual fruit weight and number of fruits per cluster (Ashrafuzzman et al. 2010), biomass production (Srivastava et al. 2016), pollen viability and fruit set per cent (Panthee et al. 2018) have direct bearing on the yield, was manifested in this work too. The finding of Alam et al. 2010; Rajashekar et al. 2006; Ashrafuzzman et al. 2010; Hossain et al. 2014 were concomitant with the current work.

\section{Heat Susceptibility Index (HSI)}

The assessment of reaction of investigated genotypes to heat was further done by estimating Heat Susceptibility Index for pollen viability, fruit set per cent, average fruit weight, and yield per plant.

Figure 3 displays the HSI of investigated genotypes for pollen viability in the range from -1.71 to 4.41. The HSI values (below 0.5) of nine genotypes viz; EC-165395, EC-165690, EC-165700, EC-620376, EC620378, EC-620387, EC-620406, EC-620410 and Pusa Ruby indicated the heat tolerance. The genotypes EC164263, EC-538153, EC-620389, EC-620395, EC-620401, EC-620417, EC-631369, Arka Saurabh and Anagha 
exhibited higher HSI values (from 0.5 to 1.0), still within the limits and could be considered as moderately heat tolerant. The surviving genotypes were heat susceptible for pollen viability (HSI value exceeding 1). It speaks for a measure of genotypic potential under heat stress, but does not account for the differences in pollen viability among the genotypes (Ahmad et al. 2003; Singh et al. 2017). The importance of HSI for pollen viability has been put forward formerly (Srivasthava et al. 2016; Singh et al. 2017).

The HSI of investigated genotypes for fruit set per cent is portrayed in Figure 4. The genotypes EC164263, EC-164563, EC-164670, EC-620387, EC-620389, EC-620401, EC-620410, EC-631369, Pusa Ruby and Arka Alok were heat tolerant for fruit set per cent. Seven genotypes EC-165395, EC-165700, EC-538153, EC-620378, EC-620406, Akshaya and Anagha suggested the moderate susceptibility. The negative magnitude for susceptibility index indicated the more intense fruit set of the genotypes under stress (Zdravkovic et al. 2013). The HSI value of tomato for fruit set per cent was documented by as well (Singh et al. 2017).

The HSI values for average fruit weight plotted on Figure 5 displayed negative HSI values for heat tolerant genotypes EC-528368, EC-538153, EC-620376, EC-620389, EC-620406, Arka Saurabh, Arka Alok and Akshaya. The genotypes EC-620382, EC-620410, EC-620417, EC-620429, and Anagha exhibited heat tolerance as well. The higher level of moderate heat tolerance was disclosed for EC-620401. The HSI for average fruit weight has also been proposed by Srivastava et al. 2016.

The HSI for yield per plant in Figure 6 plotted values from -9.07 to 7.22. The genotypes EC-151568, EC-164263, EC-249514, EC-528368, EC-620378, EC-620382, EC-620387, EC-620389, EC-620395, EC620401, EC-620406, EC-620410, Pusa Ruby, Arka Saurabh and Akshaya indicated the heat tolerance. The moderate heat tolerance HSI values were stretching from 0.75 (Anagha) to 0.98 (EC-165395). There was consistency in results with Srivastava et al. 2016.

The heat tolerant genotypes EC-620387, EC-620389, EC-620401, EC-620406, EC-620410 and Pusa Ruby for reproductive traits were heat tolerant for yield per plant as well. In contrast, the heat tolerant genotypes EC-249514, EC-620382, EC-620395, Arka Saurabh and Akshaya for yield per plant nowhere appeared for hotset distinctions. The genotypes EC-538153 and Anagha were moderately heat tolerant for reproductive distinctions and heat tolerant for average fruit weight. In crops occurring over a wide range of ecological and climatic habituations, isolated accessions often adapt to particular microclimate [25]. On comparison with the filed assessment, there was consistency in the results of seven genotypes viz; EC-164263, EC-538153, EC- 
620387, EC-620389, EC-620401, EC-620406 and EC-620410 for combined effects of reproductive and yield traits.

\section{Multivariate analysis}

The final estimation of genotypes in the selection process involved the use of cluster method classifying different genotypes in similar classes. The analysis distributed genotypes into five clusters based on genetic divergence (Table 3). Cluster II was the largest group containing 15 genotypes. The formation of five clusters indicated the existence of divergence of population as suggested by Ahmad et al. 2003; Basavaraj et al. 2010.

The $\mathrm{D}^{2}$ technique measures the forces of differentiation at two levels, intra-cluster and inter-cluster. The inter-cluster distance was greater than intra-cluster distance (Table 4) propounding the existence of homogeneous nature within and heterogeneous nature among the clusters and, Reddy et al. 2013b; Dar et al. 2015; Lekshmi and Celin 2015; Meena and Bahadur 2015; Kumar et al. 2016 see eye to eye the investigation. The $\mathrm{D}^{2}$ technique is thus practically advantageous for the selection of genetically divergent parents for the exploitation in the hybrid vigour (Lekshmi and Celin 2015).

The contribution of each trait to the variations was reflected in the cluster mean value (Table 5). The present investigation was focussed on hotset genotypes. Common features were identified in Cluster II regarding flowers as lowest exerted stigma (20.36\%), highest pollen viability $(57.89 \%)$ and highest fruit set per cent (58.0\%), and covered the hotset genotypes chiefly. In this cluster the relative proportion of average fruit weight and yield per plant remained higher. Amidst the fifteen genotypes of Cluster II, 14 were included in the heat tolerant and moderately tolerant classification in the susceptibility index. Cluster $\mathrm{V}$ had a very different growth pattern. The response was individualistic with noticeable earliness and thick-walled fruits. On the contrary, small fruited phenotypes of Cluster I were associated with poor fruit set per cent, and thin pericarp. Chernet et al. 2014; Iqbal et al. 2014; Lekshmi and Celin 2015; Meena and Bahadur 2015 had previously given the clustering of tomato genotypes to identify the differences and relationships among them.

Heat stress and its hurtful conclusions on the crop production are altogether habitual in summer on account of global warming. Analysis of natural diversity in the germplasm, has led to the identification of different tolerance index and grouping of genotypes. In this context the current investigation employed three modules for the comparative performance of the genotypes under stressed and non-stressed conditions. The 
ANOVA results of phenotypic analysis has shown a high level of heterogeneity and thus, represented a desirable source of genetic variability, and concluded that the genotypes EC-165395, EC-165690, EC-620401, EC620406 and EC-620410 noted less proportion of flowers with exerted stigma, pollen viability and fruit set per cent exceeding 60\% and superior yield per plant for both the seasons. Besides these genotypes EC-164263, EC538153, EC-620382, EC-620389, EC-620395 and EC-631369 noted yield per plant over $1200 \mathrm{~g}$ for both the seasons, and this variation is thought to be adaptive to the local environment in the case of yield per plant. The absence of comprehend thermo-tolerant genotypes with reference to the traits investigated, hinted the short coming of selective power in the seasonal appraisal. In the case, the evaluation reaction of investigated genotypes to heat was done by using Heat Susceptibility Index as well. The focus was on the pollen viability, fruit set per cent, average fruit weight and yield per plant. Several outperforming individuals were identified in each trait. The results indicated the suitability of EC-538153, EC-620382, EC-620395, EC-620401, EC-620406 and EC-620410 genotypes for the inclusion in the hybridisation programmes. Another important analysis was the multivariate analysis based on genetic divergence, and the clustering pattern corresponding to specific characteristics. The analysis reasoned that the genetic diversity overcome the limitations in the field and help unravelling breeding modules for heat tolerance. Identification of clusters with hotset distinctions would be a logical step for the identification and execution of the trait. Altogether, the current work supports the existence of EC-164263, EC- 620387, EC-620389, EC-620401, EC-620406 and EC-620410 hotset genotypes for improvement of heat tolerance. A peculiar genotype with earliness and thick pericrap (Cluster V EC-620427) was also identified. the results also support the existing distinct screening modules for the identification of stable heat tolerant genotypes. The new insights gained and the wealth of data furnished from this investigation can contribute much to the refinement of current breeding models for stress tolerance. Clustering pattern could be utilized in choosing parents for hybridisation likely to generate the highest possible variability for the economic characters. Heat stress is often connected with drought stress in field conditions, which demand the integrated study of heat and drought stress that boosts the current work. Extra work on chlorophyll content can ameliorate the work as well. since heat tolerance hangs on multiple traits, the strategy cited and available set of genotypes therefore will help in deciphering the genetic layout fundamental in tolerance mechanism and illuminate on the future breeding proposals for stress tolerance.

\section{References}


Abdul-Baki AA (1992) Determination of pollen viability in tomato. J. Am. Soc. Hortic. Sci. 117:473-476.

Adams SR, Cockshull KE, Cave CRJ (2001) Effect of temperature on the growth and development of tomato fruits. Ann. Bot. 88:869-877

Agele SO, Olufayo A, Iremiren GO (2002) Effects of season of sowing on water use and yield of tomato in the humid south of Nigeria. Afr. Crop Sci. J. 10:231-237

Ahmad R, Qadir S, Ahmad N, Shah KH (2003) Yield potential and stability of nine wheat varieties under water stress conditions. Int. J. Agric. Biol. 5:7-9

Alam MS, Sultana N, Ahmad S., Hossain MM, Islam AKMA (2010) Performance of heat tolerant tomato hybrid lines under hot, humid conditions. Bangladesh J. Agric. Res. 35:367-373

Alsamir M, Ahmad NM, Keitel C, Mahmood T, Trethworn R (2017) Identification of high temperature tolerant and agronomicaly viable tomato (Solanum lycopersicum) genotypes from diverse germplasm collection. Adv. Crop Sci. Tech. 5:299

Ashrafuzzman M, Haque MA, Ismail MR, Islam MT, Shahidullah SM (2010) Genotypic and seasonal variation in plant development and yield attributes in tomato (Lycopersicum esculentum Mill.) cultivars. Int. J. Bot. 6:4146

Barnab B, Jager K, Feher A (2008) The effect of drought and heat stress on reproductive processes in cereals. Plant Cell Environ. 31:11-38.

Basavaraj NS, Patil BC, Salimath PM, Hosamani RM, Krishnaraj PU (2010) Genetic divergence in tomato (Solanum lycoperiscon [Mill.] Wettsd.). Karanatka J. Agric. Sci. 23:508-539

Camejo D, Pedro R, Angles M (2005) High temperature effects on photosynthetic activity of two tomato cultivars with different heat susceptibility. J. Plant Physiol. 162:281-289

Chernet S, Belew D, Abay F (2014) Genetic variability and association of characters in tomato (Solanum lycoperiscon L.) genotypes in northern Ethiopia. Int. J. Agric. Res. 8:67-76

Cheniclet C, Rong WY, Causse M, Frangne N, Bolling L, Carde JP, Renaudin JP (2005) Cell expansion and endoreduplication show a large genetic variability in pericarp and contribute strongly to tomato fruit growth. Plant Physiol. 139:1984-1994

Dar RA, Sharma JP, Mushtaq A (2015) Genetic diversity among some productive genotypes of tomato (Lycopersicon esculentum Mill.). Afr. J. Biotechnol. 14:1846-1853

Darawshesh MK, Bouranis DL (2006) Season-dependent fruit loading: effect of dry mass, water and nitrogen allocation in tomato plants. J. Plant Nutr. 29:347-359 DOI: 10.1080/01904160500476962 
Dhillon NS, Sharma P, Kumar P, Sharma V (2019) Assessment of tomato hybrids for yield and quality attributes under protected environment. Int. J. Curr. Microbiol. App. Sci. 8: 256- 2962 https://doi.org/10.1007/ s10681-017-1949-6

Din JU, Khan SU, Qayyum A, Abbasi KS, Jenks MA (2015) Evaluation of potential morpho-physiological and biochemical indicators in selecting heat-tolerant tomato (Solanum lycopersicum Mill.) genotypes. Hortic. Environ. Biotechnol. 56:769-776

Driedonks N, Wolters-Arts M, Huber H, de Boer G-J, Vriezen W, Mariani C, Rieu I (2018) Exploring the natural variation for reproductive thermotolerance in wild tomato species. Euphytica 214:67

Estelitta S, Bonny PB, Helen S, Suma A (2016) Package of practices recommendations: crops. Kerala Agricultural University, Thrissur

Fisher RA (1967) The collected papers of R A Fisher. Adelaide, South Australia, MR0505093

Fisher RA, Maurer R (1978) Drought resistance in spring wheat cultivars I grain yield responses in spring wheat. Aust. J. Agric. Sci. 29:892-912

Giorno F, Wolters-Arts M, Mariani C, Rieu I (2003) Ensuring reproduction at high temperatures: the heat stress response during anther and pollen development. Plants 2:489-506

Gonzalo MJ, Li Y-C, Chen K-Y, Gil D, Montoro T, Najera I, Baixauli I, Granell A, Monforte AJ (2020) Genetic control of reproductive traits in tomato under high temperature. Front. Plant Sci. 11:326

Hameeda M, Keitel C, Ahmad N, Mahmood T, Trethwan R (2015) Screening of tomato germplasm for heat stress tolerance. Procedia Environ. Sci. 29:173-174

Hazra P, Ansary SH, Sikder D, Peter KV (2007) Breeding tomato (Lycopersicum esculentum Mill) resistant to high temperature. Int. J. Plant Breed. 1:31-40

Hedhly A, Hormaza JI, Herrero M (2008) Global warming and sexual plant reproduction. Trends Plant Sci. $14: 30-36$.

Hossain MF, Ara N, Uddin MS, Islam MR, Kaisar MO (2014) Effect of sowing dates in flowering, fruit setting and yield of tomato genotypes. J. Agric. Res. 4:547-553

Ilker KO, Tatar F, Tonk A, Tosun M (2011) Determination of tolerance level of some wheat genotypes to postanthesis drought. Turk. J. field Crops. 16, 59-63

Iqbal Q, Saleem MY, Hameed A, Asghar M (2014) Assessment of genetic divergence in tomato through agglomerative hierarchical clustering and principal component analysis. Pakisthan J. Bot. 46:1865-1870 
Jha UC, Bohra A, Singh NP (2014) Heat stress in crop plants: its nature, impacts and integrated breeding strategies to improve heat tolerance. Plant Breed. 133:697-701

Kumar PA, Reddy KR, Reddy RVSK, Panravada SR, Saidahai P (2016) Genetic divergence studies in tomato. Bioscan 11:3071-3074

Lekshmi SL, Celin VA (2016) Genetic diversity studies in tomato (Solanum lycoperiscon L.) under protected conditions. Int. J. Microbiol. App. Sci. 5:212-217

Li SM, Chen DU, Xuzn WX, Wei ZD, Chang GJ, Shu DS (2005) Changes of endogenous abscisic acid and the effect of exogenous ABA on pollen genrmination under heat stress tomato. Acta. Hortic. 32:234-238

Meena OP, Bahadur V (2015) Breeding potential of indeterminate tomato (Solanum lycopersicum L.) accessions using $\mathrm{D}^{2}$ analysis. SABRAO J. Breed. Genet. 47:49-59

Musseau C, Just D, Jorly J, Gevaudant F, Moing A, Chevaliar C, Lemaire-Chamley M, Rothan C, Fernandez L (2017) Identification of two new mechanisms that regulate fruit growth by cell expansion in tomato. Front. Plant Sci. 8:988

Oladitan TO, Oluwasemire KO (2018) Influence of weather conditions on selected tomato varieties in response to season of sowing in akure, a rainforest zone of Nigeria. Art Human Open Acc. J. 2:422-426

Pan C, Yang D, Zhao X, Jiao C, Yan Y, Tumbeh A, Lamin-Samu, Wang Q, Xu X, Fei Z, Lu G (2018) Tomato stigma exsertion induced by high temperature is associated with the jasmonate signalling. Plant Cell Environ. doi: $10.1111 /$ pce. 13444

Panthee DR, Kressin JP, Piotrowski A (2018) Heritability of flower number and fruit set under heat stress in tomato. HortScience 53:1294-1299

Paupiere MJ, van Huesden AW, Bovy AG (2014) The metabolic basis of pollen thermo-tolerance: perspectives for breeding. Metabolites 4:889-920

Pressman E, Peet MM, Pharr DM (2002)The effect of heat stress on tomato pollen characteristics is associated with changes in carbohydrate concentration in the developing anthers. Ann. Bot. 90:631-636

Rajashekar BS, Kalappa VP, Vishwanath K (2006) Effect of planting season on seed yield and quality of tomato varieties resistant to leaf curl virus. Seed Res. 34:223-225

Rao CR (1952) Advance statistical methods in biometric research; John Wiley and Sons , New York.

Razzaq MK, Rauf S, Khurshid M, Iqbal S, Bhat JA, Farzand A, Riaz A, Xing G, Gai J (2019) Pollen viability an index of abiotic stress tolerance and methods for the improved pollen viability. Pak. J. Agric. Res. 32:609-624

Reddy BR, Reddy MP, Reddy DS, Begum H (2013a) Correlation and path analysis studies for yield and quality traits in tomato. J. Agric. Vet. Sci. 4:56-59

Reddy BR, Reddy DS, Reddaiah K, Sunil N (2013b) Studies on the genetic variability, heritability, and genetic advance for yield and quality traits in Tomato (Solanum lycoperiscon L.). Int. J. Curr. Microbiol. Appl. Sci. 
Renaudin J-P, Deluche C, Cheniclet C, Chevalier C, Frangne N (2017) Cell layer-specific pattern of cell division and expansion during fruit set and fruit growth in tomato pericarp. J. Exp. Bot. 68:1613-1623

Ruggieri V, Calafiore R, Schettini C, Rigano MM, Olivieri F, Frusciante L, Amalia B (2019) Exploiting genetic and genomic resources to enhance heat tolerance in tomatoes. Agron. 9:22 https://doi.org/10.3390/agronomy9010022

Sato S, Peet MM, Thomas JF (2002) Determining critical pre- and post-anthesis periods and physiological processes in Lycopersicon esculentum Mill. exposed to moderately elevated temperature. J. Exp. Bot. 53:11871195

Sato S, Kamiyama M, Iwata T, Makita N, Furukawa H, Ikeda H (2006) Moderate increase of mean daily temperature adversely affects fruit set of Lycopersicon esculentum by disrupting specific physiological processes in male reproductive development. Ann. Bot. 97:731-738. https://doi. org/10.1093/aob/mc1037

Saeed A, Hayat K, Khan AA, Iqbal S (2007) Heat tolerance studies in tomato (Lycopersicon esculentum Mill.). Int. J. Agric. Biol. 9:649-652

Singh T, Singh N, Bahuguna A, Nautiyal M, Sharma VK (2014) Performance of tomato (Solanum lycopersicum) hybrids for growth, yield and quality inside polyhouse under mid-hill conditions of Uttarakhand. Am. J. Drug Discov. Dev. 4: 202-209

Singh U, Patel PK, Singh AK, Tiwari V, Kumar R, Rai N, Bahadur A, Tiwari SK, Singh M, Singh B (2015) Screening of tomato genotypes under high temperature stress for reproductive traits. Veg. Sci. 42:52-55 Singh AK, Singh RP, Singh K, Singh MK, Singh AK, Singh U (2017) Fatalities due to seasonal variations in tomato genotypes. Int. J. Curr. Microbiol. Appl. Sci. 6:2434-2441

Srivastava K, Kumar S, Bhandari HR, Vaishampayan A (2016) Search for tomato hybrids suited for high temperature stress conditions. In: proceedings of the SABRAO $13^{\text {th }}$ congress and international conference, Bogor, Indonesia, 14-16 September 2016; pp. 137-150

Stone P (2001) The effects of heat stress on cereal yield and quality In: Basra AS (ed) Crop responses and adaptations to temperature stress, Food Products Press: Binghamton, New York, pp 243-291.

Tolessa K, Heuvelink EP (2018) Pollen viability and fruit set of tomato introgression lines (Solanum esculentum XL. chmielewskii) at moderately high temperature regimens. World App. Sci. J. 36:29-38

Xu J, Wolters-Arts M, Mariani C, Huber H, Rieu I (2017a) Heat stress affects vegetative and reproductive performance and trait correlations in tomato. Euphytica 213:156. 
Xu J, Driedonks N, Rutten MJM, Vriezen WH, de Boer G-J, Rieu I (2017b) Mapping quantitative trait loci for heat tolerance of reproductive traits in tomato (Solanum lycopersicum). Mol. Breed. 37:37-58 https://doi.org/10.1007/s11032-017-0664-2

Zamir D (2001) Improving plant breeding with exotic genetic libraries. Nat. Rev. Genet. 2: 983-989

Zdravkovic J, Jovanovic Z, Djordjevic M, Girek Z, Zdravkovic M, Stikic R (2013) Applications of stress susceptibility index for drought tolerance screening of tomato populations. Genetika 45: 679-689

Zinn KE, Tinc-Ozdemir M, Harper JF (2010) Temperature stress and plant sexual reproduction: uncovering the weakest links. J. Exp. Bot. 61:1959-1968.

Zhou R, Yu XQ, Ottosen CO, Rosenqvist LP, Zhao YL, Wang YL, Yu WG, Zhao TM, Wu Z (2017) Drought stress had a prominent effect over heat stress on three tomato cultivars subjected to combined stress. BMC Plant Biol. 17:24 
Table 1: Performance of tomato genotypes for reproductive distinctions

\begin{tabular}{|c|c|c|c|c|c|c|c|c|c|}
\hline \multirow[t]{2}{*}{$\begin{array}{l}\text { Sl. } \\
\text { No. }\end{array}$} & \multirow[t]{2}{*}{ Genotypes } & \multicolumn{2}{|c|}{$\begin{array}{l}\text { Flowers with } \\
\text { exerted stigma } \\
(\%)\end{array}$} & \multicolumn{2}{|c|}{$\begin{array}{l}\text { Pollen viability } \\
(\%)\end{array}$} & \multicolumn{2}{|c|}{ Fruit set per cent } & \multicolumn{2}{|c|}{$\begin{array}{l}\text { Number of fruits } \\
\text { per cluster }\end{array}$} \\
\hline & & Summer & Rainy & Summer & Rainy & Summer & Rainy & Summer & Rainy \\
\hline 1 & EC-145057 & 22.9 & 27.3 & 44.2 & 55.3 & 34.8 & 55.0 & 2.2 & 4.0 \\
\hline 2 & EC-151568 & 35.1 & 30.8 & 46.6 & 54.1 & 34.6 & 44.6 & 2.1 & 3.2 \\
\hline 3 & EC-157568 & 25.2 & 31.1 & 45.5 & 53.3 & 39.9 & 59.4 & 2.7 & 3.3 \\
\hline 4 & EC-160885 & 41.7 & 31.1 & 50.4 & 58.2 & 32.9 & 45.6 & 2.9 & 3.2 \\
\hline 5 & EC-163605 & 39.8 & 27.5 & 45.6 & 55.3 & 34.8 & 58.1 & 2.6 & 3.3 \\
\hline 6 & EC-164263 & 19.0 & 18.2 & 59.7 & 61.6 & 62.4 & 56.0 & 3.0 & 3.7 \\
\hline 7 & EC-164563 & 28.7 & 20.7 & 52.8 & 58.4 & 58.1 & 43.0 & 2.6 & 2.8 \\
\hline 8 & EC-164670 & 23.1 & 23.4 & 42.7 & 54.7 & 50.1 & 51.4 & 2.7 & 3.7 \\
\hline 9 & EC-165395 & 21.4 & 21.0 & 64.4 & 65.4 & 62.5 & 66.8 & 6.0 & 5.7 \\
\hline 10 & EC-165690 & 21.0 & 20.4 & 63.2 & 63.8 & 60.3 & 66.4 & 6.0 & 6.2 \\
\hline 11 & EC-165700 & 50.1 & 14.0 & 61.6 & 59.6 & 43.5 & 47.1 & 2.5 & 2.5 \\
\hline 12 & EC-249514 & 42.0 & 18.0 & 47.4 & 52.7 & 48.9 & 54.0 & 3.0 & 3.5 \\
\hline 13 & EC-521067 B & 25.6 & 24.1 & 43.7 & 50.1 & 61.4 & 45.6 & 3.7 & 3.4 \\
\hline 14 & EC-528368 & 27.8 & 25.2 & 58.3 & 63.5 & 39.8 & 51.4 & 4.3 & 3.8 \\
\hline 15 & EC-538153 & 23.8 & 12.1 & 60.2 & 63.3 & 53.4 & 57.0 & 2.0 & 2.7 \\
\hline 16 & EC-620376 & 25.0 & 35.6 & 63.0 & 62.9 & 50.4 & 57.5 & 3.0 & 3.8 \\
\hline 17 & EC-620378 & 23.9 & 17.2 & 55.6 & 51.1 & 53.2 & 56.9 & 3.0 & 4.4 \\
\hline 18 & EC-620382 & 56.9 & 30.0 & 42.6 & 55.0 & 44.1 & 50.2 & 3.4 & 4.0 \\
\hline 19 & EC-620387 & 22.0 & 24.3 & 60.6 & 62.1 & 59.1 & 60.7 & 2.2 & 2.7 \\
\hline 20 & EC-620389 & 25.0 & 26.6 & 60.4 & 63.5 & 58.9 & 59.0 & 2.2 & 2.2 \\
\hline 21 & EC-620395 & 23.3 & 17.7 & 53.5 & 56.3 & 56.8 & 63.5 & 3.4 & 3.4 \\
\hline 22 & EC-620401 & 19.6 & 17.1 & 62.1 & 64.6 & 63.2 & 64.7 & 4.5 & 4.5 \\
\hline 423 & EC-620406 & 23.3 & 23.9 & 61.6 & 63.2 & 63.4 & 67.4 & 4.5 & 4.3 \\
\hline 24 & EC-620410 & 22.0 & 16.1 & 62.7 & 64.0 & 63.8 & 63.5 & 4.5 & 4.1 \\
\hline 25 & EC-620417 & 22.1 & 17.3 & 57.9 & 60.9 & 55.7 & 62.1 & 2.4 & 3.1 \\
\hline 26 & EC-620427 & 36.4 & 33.8 & 47.5 & 53.3 & 45.1 & 57.4 & 3.1 & 3.5 \\
\hline 27 & EC-620429 & 32.6 & 33.2 & 45.3 & 54.5 & 41.1 & 51.3 & 3.1 & 3.6 \\
\hline 28 & EC-631369 & 25.2 & 24.9 & 59.4 & 61.6 & 60.1 & 58.7 & 1.9 & 2.9 \\
\hline 29 & EC-631379 & 23.5 & 15.1 & 59.0 & 63.7 & 54.0 & 65.4 & 3.0 & 3.2 \\
\hline 30 & Pusa Ruby & 24.6 & 27.6 & 48.6 & 49.0 & 51.1 & 49.1 & 3.0 & 2.6 \\
\hline 31 & Arka Abha & 37.0 & 36.5 & 49.5 & 55.0 & 47.6 & 55.3 & 3.4 & 3.7 \\
\hline 32 & Arka Saurabh & 29.2 & 15.8 & 50.4 & 53.1 & 46.9 & 53.5 & 2.7 & 3.0 \\
\hline 33 & Arka Alok & 35.0 & 22.1 & 46.0 & 54.9 & 45.7 & 44.9 & 2.4 & 2.8 \\
\hline 34 & Akshaya & 31.9 & 19.8 & 48.9 & 54.8 & 57.0 & 61.0 & 4.0 & 4.0 \\
\hline \multirow[t]{3}{*}{35} & Anagha & 27.9 & 21.7 & 52.8 & 54.8 & 57.4 & 60.8 & 3.5 & 3.5 \\
\hline & $\mathrm{CD}(0.05)$ & 1.3 & 8.3 & 4.6 & 6.3 & 6.5 & 7.1 & 1.1 & 1.2 \\
\hline & $\mathrm{CV}$ & 16.4 & 13.6 & 5.2 & 5.6 & 5.9 & 12.5 & 12.2 & 16.6 \\
\hline
\end{tabular}


Table 2: Performance of tomato genotypes for days to first fruit set and yield features

\begin{tabular}{|c|c|c|c|c|c|c|c|c|c|c|c|}
\hline \multirow[t]{2}{*}{$\begin{array}{l}\text { Sl. } \\
\text { No. }\end{array}$} & \multirow[t]{2}{*}{ Genotypes } & \multicolumn{2}{|c|}{$\begin{array}{l}\text { Days to first fruit } \\
\text { set (number of } \\
\text { days) }\end{array}$} & \multicolumn{2}{|c|}{$\begin{array}{l}\text { Average fruit } \\
\text { weight }(\mathrm{g})\end{array}$} & \multicolumn{2}{|c|}{$\begin{array}{l}\text { Pericarp } \\
\text { thickness }(\mathrm{cm})\end{array}$} & \multicolumn{2}{|c|}{$\begin{array}{l}\text { Number of } \\
\text { fruits per plant } \\
\text { (number) }\end{array}$} & \multicolumn{2}{|c|}{ Yield per plant $(\mathrm{g})$} \\
\hline & & Summer & Rainy & Summer & Rainy & Summer & $\begin{array}{l}\text { Rain } \\
\text { y }\end{array}$ & Summer & Rainy & Summer & Rainy \\
\hline 1 & EC-145057 & 39.0 & 49.8 & 35.5 & 31.6 & 0.52 & 0.47 & 17.3 & 20.0 & 452.1 & 623.3 \\
\hline 2 & EC-151568 & 37.8 & 42.1 & 38.5 & 32.1 & 0.6 & 0.56 & 33.6 & 43.5 & 745.6 & 639.8 \\
\hline 3 & EC-157568 & 41.4 & 44.4 & 37.6 & 31.1 & 0.44 & 0.63 & 15.8 & 16.0 & 430.1 & 578.6 \\
\hline 4 & EC-160885 & 39.6 & 47.5 & 44.4 & 32.5 & 0.53 & 0.47 & 35.8 & 12.1 & 378.3 & 470.6 \\
\hline 5 & EC-163605 & 40.1 & 47.3 & 45.9 & 29.3 & 0.27 & 0.52 & 18.7 & 17.6 & 462.9 & 624.3 \\
\hline 6 & EC-164263 & 35.2 & 47.8 & 73.5 & 64.2 & 0.63 & 0.42 & 27.5 & 22.4 & 1365.8 & 1436.6 \\
\hline 7 & EC-164563 & 34.4 & 48.4 & 58.0 & 44.5 & 0.67 & 0.54 & 19.5 & 19.6 & 643.2 & 947.6 \\
\hline 8 & EC-164670 & 38.1 & 45.9 & 46.5 & 31.8 & 0.46 & 0.5 & 18.0 & 23.1 & 475.4 & 963.6 \\
\hline 9 & EC-165395 & 39.2 & 44.0 & 25.1 & 21.9 & 0.43 & 0.4 & 67.6 & 65.6 & 1375.4 & 1505.8 \\
\hline 10 & EC-165690 & 34.1 & 44.3 & 28.4 & 23.2 & 0.42 & 0.41 & 71.9 & 67 & 1452.2 & 1688.3 \\
\hline 11 & EC-165700 & 34.7 & 48.8 & 12.2 & 4.2 & 0.29 & 0.21 & 34.4 & 39.6 & 390.5 & 448.8 \\
\hline 12 & EC-249514 & 36.2 & 40.8 & 55.3 & 43.1 & 0.38 & 0.51 & 18.8 & 15.3 & 787.4 & 776.1 \\
\hline 13 & EC-521067 B & 42.1 & 38.7 & 48.7 & 33 & 0.5 & 0.5 & 16.6 & 19.1 & 680.2 & 840 \\
\hline 14 & EC-528368 & 45.1 & 47.7 & 11.2 & 14.3 & 0.49 & 0.18 & 28.5 & 44.2 & 289.7 & 160.4 \\
\hline 15 & EC-538153 & 37.2 & 45.4 & 94.2 & 95.3 & 0.48 & 0.76 & 19.2 & 19.3 & 1262.6 & 1522.6 \\
\hline 16 & EC-620376 & 38.7 & 35.4 & 10.9 & 13.6 & 0.44 & 0.29 & 42.5 & 46.9 & 146.7 & 409.5 \\
\hline 17 & EC-620378 & 35.1 & 40.9 & 58.5 & 52.2 & 0.44 & 0.49 & 18.3 & 20.8 & 881.8 & 751.7 \\
\hline 18 & EC-620382 & 35.1 & 37.8 & 65.4 & 63.8 & 0.68 & 0.61 & 16.2 & 24 & 1208.1 & 1250.9 \\
\hline 19 & EC-620387 & 43.5 & 44.0 & 93.6 & 73.6 & 0.65 & 0.61 & 18.2 & 11.3 & 1210.6 & 930.7 \\
\hline 20 & EC-620389 & 43.3 & 46.6 & 70.2 & 72 & 0.68 & 0.76 & 19.3 & 17.9 & 1273.4 & 1135.9 \\
\hline 21 & EC-620395 & 33.2 & 42.3 & 92.4 & 91.2 & 0.64 & 0.67 & 21.9 & 17.5 & 1466.1 & 1387.7 \\
\hline 22 & EC-620401 & 34.6 & 38.6 & 89.3 & 82.7 & 0.69 & 0.78 & 21.7 & 24.8 & 1745.6 & 1764.3 \\
\hline 23 & EC-620406 & 38.2 & 36.1 & 83.3 & 85.3 & 0.84 & 0.8 & 20.2 & 23.1 & 1665.3 & 1685.6 \\
\hline 24 & EC-620410 & 39.5 & 39.2 & 90.4 & 87.5 & 0.83 & 0.75 & 22.5 & 22.4 & 1857 & 1875 \\
\hline 25 & EC-620417 & 45.8 & 43.1 & 72.4 & 72 & 0.74 & 0.71 & 19.1 & 20.6 & 1143.4 & 1375.4 \\
\hline 26 & EC-620427 & 34.2 & 39.1 & 73.2 & 62.1 & 0.74 & 0.86 & 16.1 & 17.7 & 936.2 & 1091.6 \\
\hline 27 & EC-620429 & 34.8 & 42.0 & 71.9 & 68.4 & 0.84 & 0.78 & 17.8 & 17.4 & 1026 & 1138.8 \\
\hline 28 & EC-631369 & 35.6 & 42.5 & 70.8 & 58.7 & 0.79 & 0.82 & 20.6 & 20.9 & 1192.2 & 1357.2 \\
\hline 29 & EC-631379 & 41.4 & 47.6 & 71.9 & 56.9 & 0.72 & 0.22 & 22.6 & 16.1 & 421.2 & 1074.2 \\
\hline 30 & Pusa Ruby & 35.4 & 44.2 & 38.2 & 33.8 & 0.51 & 0.31 & 19.3 & 15.2 & 509.1 & 425.1 \\
\hline 31 & Arka Abha & 34.4 & 35.8 & 72 & 62.7 & 0.54 & 0.58 & 16.1 & 19.1 & 947.2 & 1029.9 \\
\hline 32 & Arka Saurabh & 38.6 & 45.1 & 69.1 & 71.1 & 0.65 & 0.5 & 13.6 & 14.4 & 904.5 & 943.7 \\
\hline 33 & Arka Alok & 39.3 & 42.2 & 69 & 69.5 & 0.63 & 0.56 & 15.3 & 17.4 & 965.6 & 1036.4 \\
\hline 34 & Akshaya & 34.3 & 46.8 & 64.4 & 65.4 & 0.6 & 0.53 & 23.5 & 22.5 & 1209 & 1147.1 \\
\hline 35 & Anagha & 35.3 & 49.5 & 71.3 & 71.2 & 0.48 & 0.54 & 15.7 & 20.5 & 987.4 & 1057.7 \\
\hline & $\mathrm{CD}(0.05)$ & 5.5 & 4.6 & 7.1 & 8.6 & 0.3 & 0.1 & 5.6 & 7.3 & 320.5 & 379.1 \\
\hline & $\mathrm{CV}$ & 7.2 & 5.2 & 6.3 & 8.1 & 8.4 & 9.9 & 15.8 & 12.3 & 19.4 & 18.7 \\
\hline
\end{tabular}


Table 3: Clustering pattern of genotypes

\begin{tabular}{|l|lr|l|}
\hline Cluster & $\begin{array}{l}\text { Number } \\
\text { genotypes } \\
\text { cluster }\end{array}$ & $\begin{array}{l}\text { per } \\
\text { I }\end{array} 14$ & $\begin{array}{l}\text { EC-145057, EC-151568, EC-157568, EC-160885, EC-163605, EC- } \\
164563, \text { EC-164670, EC-165395, EC-165690, EC-165700, EC-521067 B } \\
\text { EC-528368, EC-620376 and Pusa Ruby }\end{array}$ \\
\hline II & 15 & $\begin{array}{l}\text { EC-249514, EC-164263, EC-620378, EC-620387, EC-620389, EC- } \\
620395, \text { EC-620401, EC-620406, EC-620410, EC-620417, EC-631369, } \\
\text { EC-631379, Arka Saurabh, Arka Alok, and Anagha }\end{array}$ \\
\hline III & 2 & EC-620382 and EC-620429 \\
\hline IV & 3 & EC-538153, Arka Abha and Akshaya \\
\hline V & 1 & EC-620427 \\
\hline
\end{tabular}

Table 4: Intra and inter-cluster distance of clusters

\begin{tabular}{|l|l|l|l|l|l|}
\hline Cluster & I & II & III & IV & V \\
\hline I & 372.06 & 1114.07 & 3242.22 & 2796.87 & 3326.62 \\
\hline II & & 277.44 & 3059.18 & 1212.69 & 3758.17 \\
\hline III & & & 33.18 & 1584.2 & 937.87 \\
\hline IV & & & & 400.63 & 985.62 \\
\hline V & & & & & 0.00 \\
\hline
\end{tabular}

Table 5: Cluster mean values for each cluster

\begin{tabular}{|l|l|l|l|l|l|}
\hline Characters & \multicolumn{4}{|l}{ clusters } \\
\hline & I & II & III & IV & V \\
\hline Flowers with exerted stigma & 23.86 & 20.36 & 31.03 & 23.88 & 32.60 \\
\hline Pollen viability & 54.78 & 57.89 & 49.34 & 55.26 & 50.40 \\
\hline Fruit set per cent & 49.48 & 58.0 & 46.65 & 55.19 & 51.20 \\
\hline Number of fruits per cluster & 3.48 & 3.24 & 3.51 & 3.29 & 3.30 \\
\hline Days to first fruit set & 41.69 & 40.70 & 37.43 & 38.98 & 36.65 \\
\hline Average fruit weight & 30.64 & 72.85 & 68.95 & 69.0 & 67.65 \\
\hline Pericarp thickness & 0.45 & 0.63 & 0.73 & 0.58 & 0.80 \\
\hline Number of fruits per plant & 28.38 & 18.61 & 20.43 & 19.50 & 16.90 \\
\hline Yield per plant & 635.77 & 1207.77 & 1155.95 & 1126.72 & 1013.90 \\
\hline
\end{tabular}




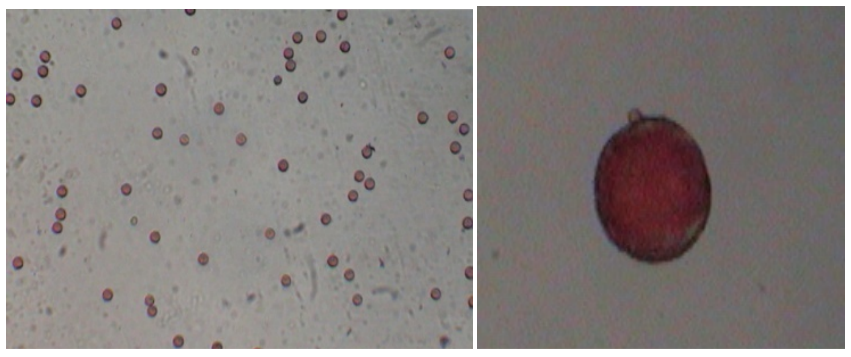

Fig1: Viable pollen grains of tomato in acetocarmine stain

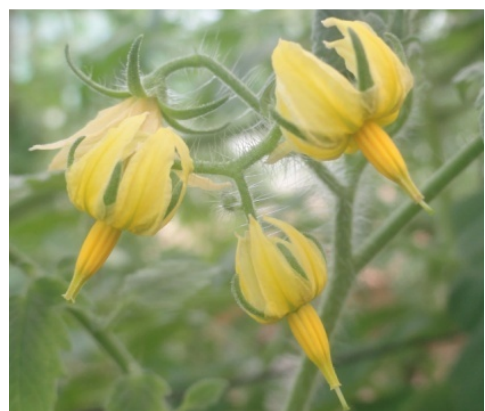

Fig 2: Flowers with introvert and extrovert stigma

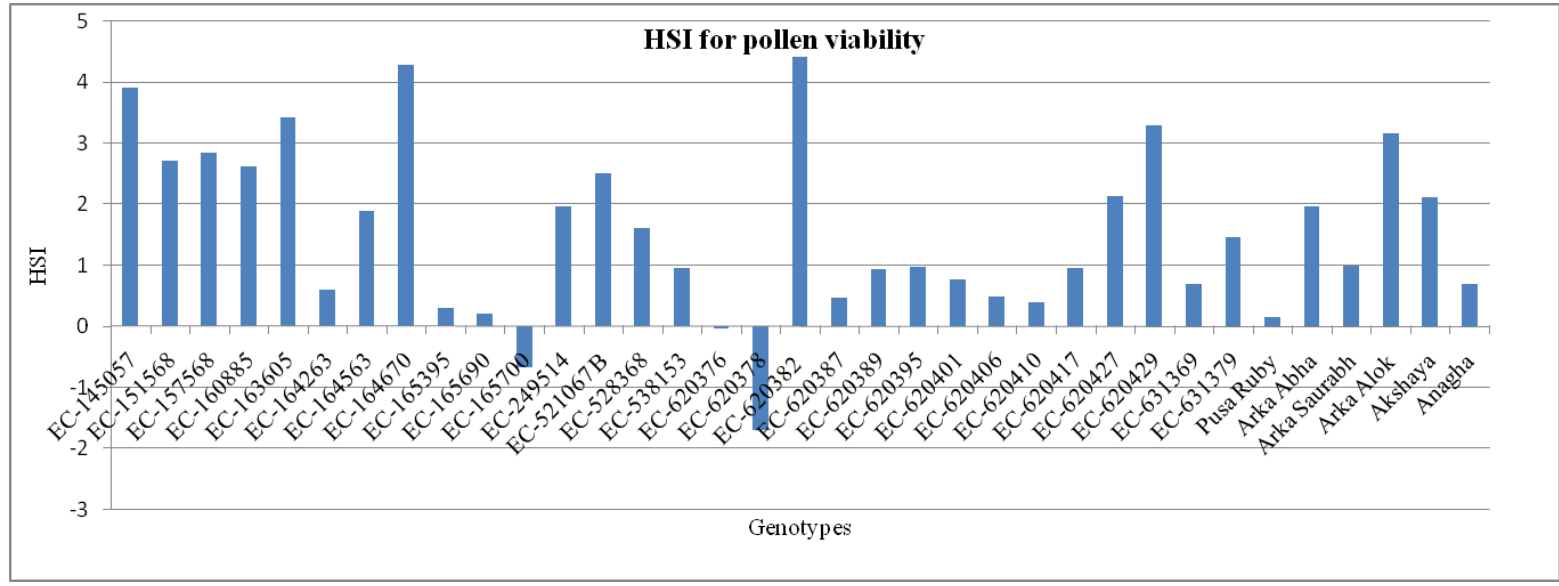

Fig 3: HSI for pollen viability of investigated genotypes

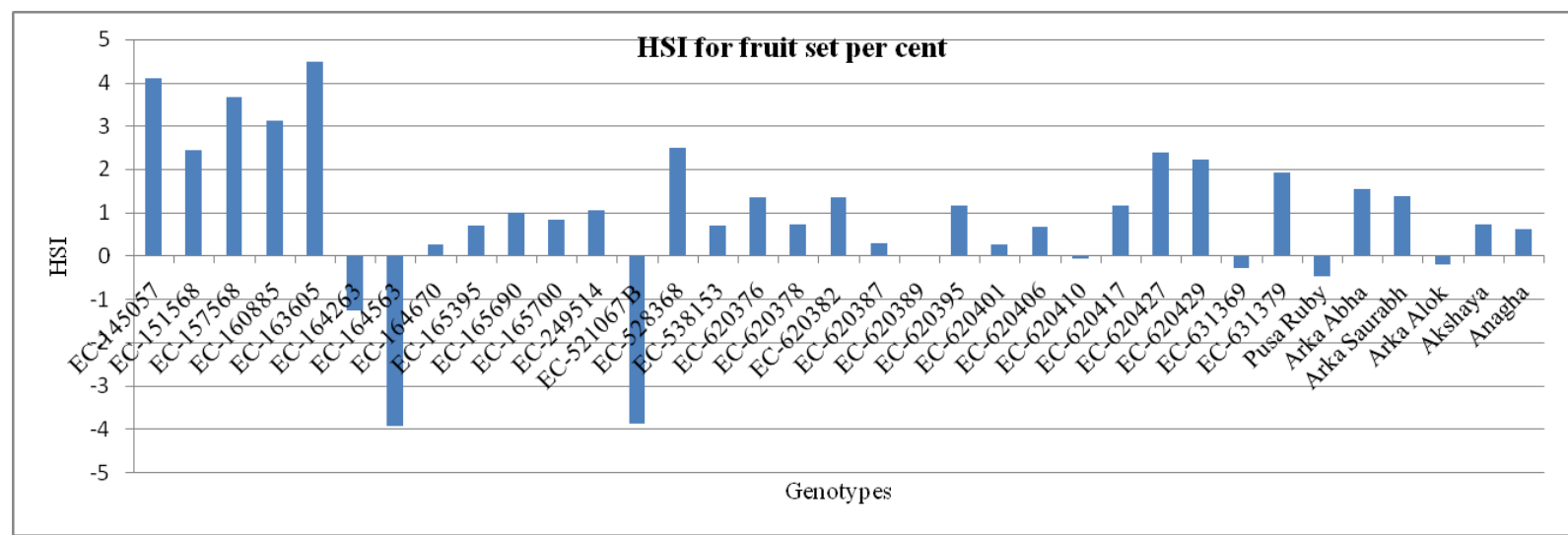

Fig 4: HSI for fruit set per cent of investigated genotypes 


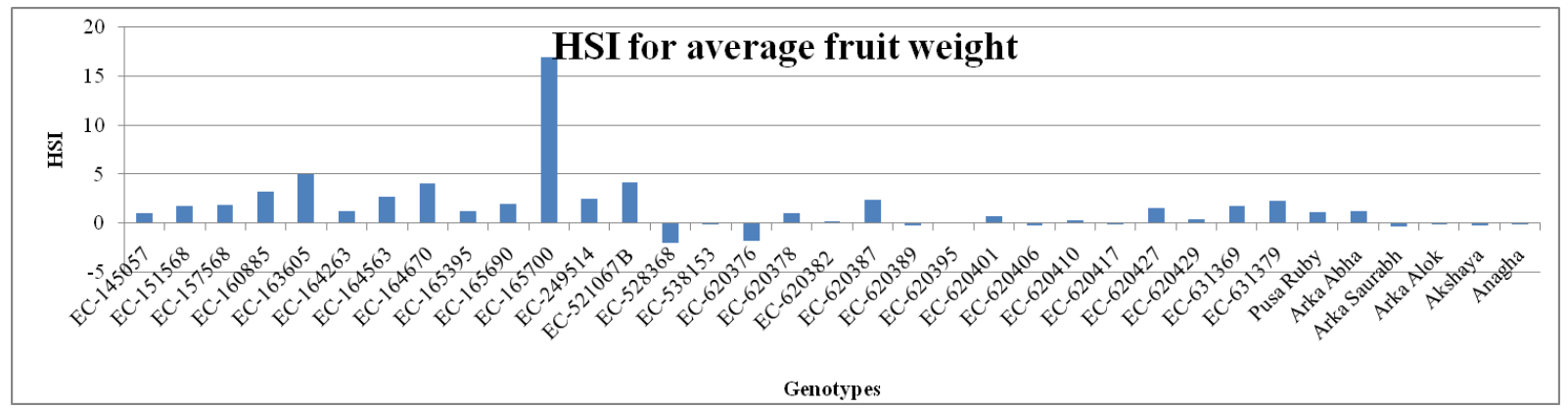

Fig 5: HSI for average fruit weight of investigated genotypes

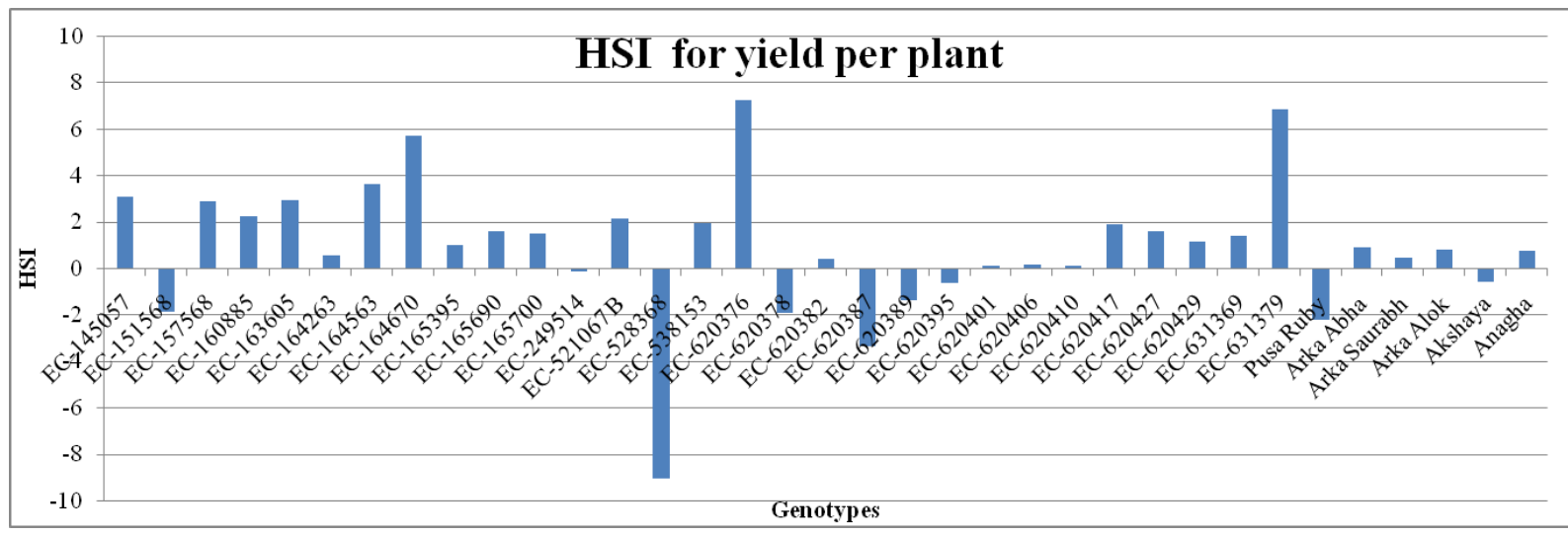

Fig 6: HSI for yield per plant of investigated genotypes 
Figures
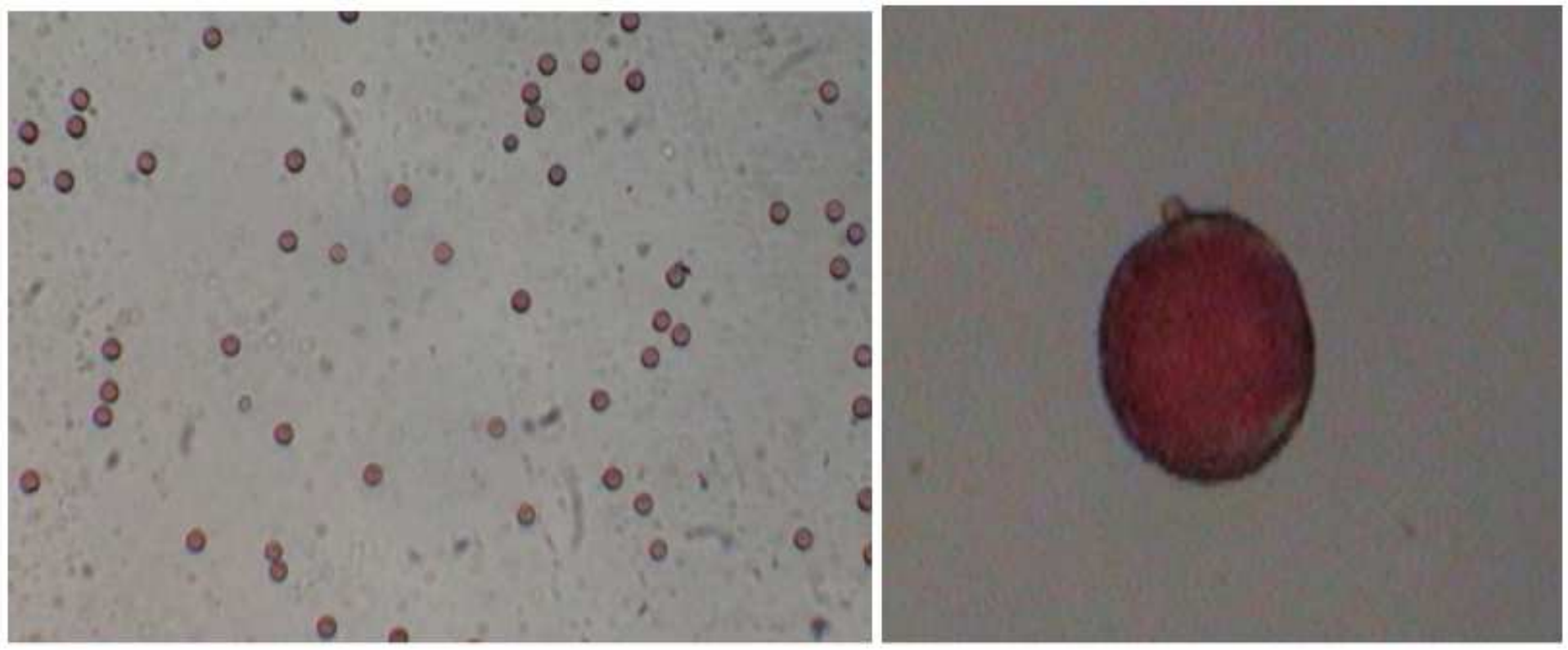

\section{Figure 1}

Viable pollen grains of tomato in acetocarmine stain

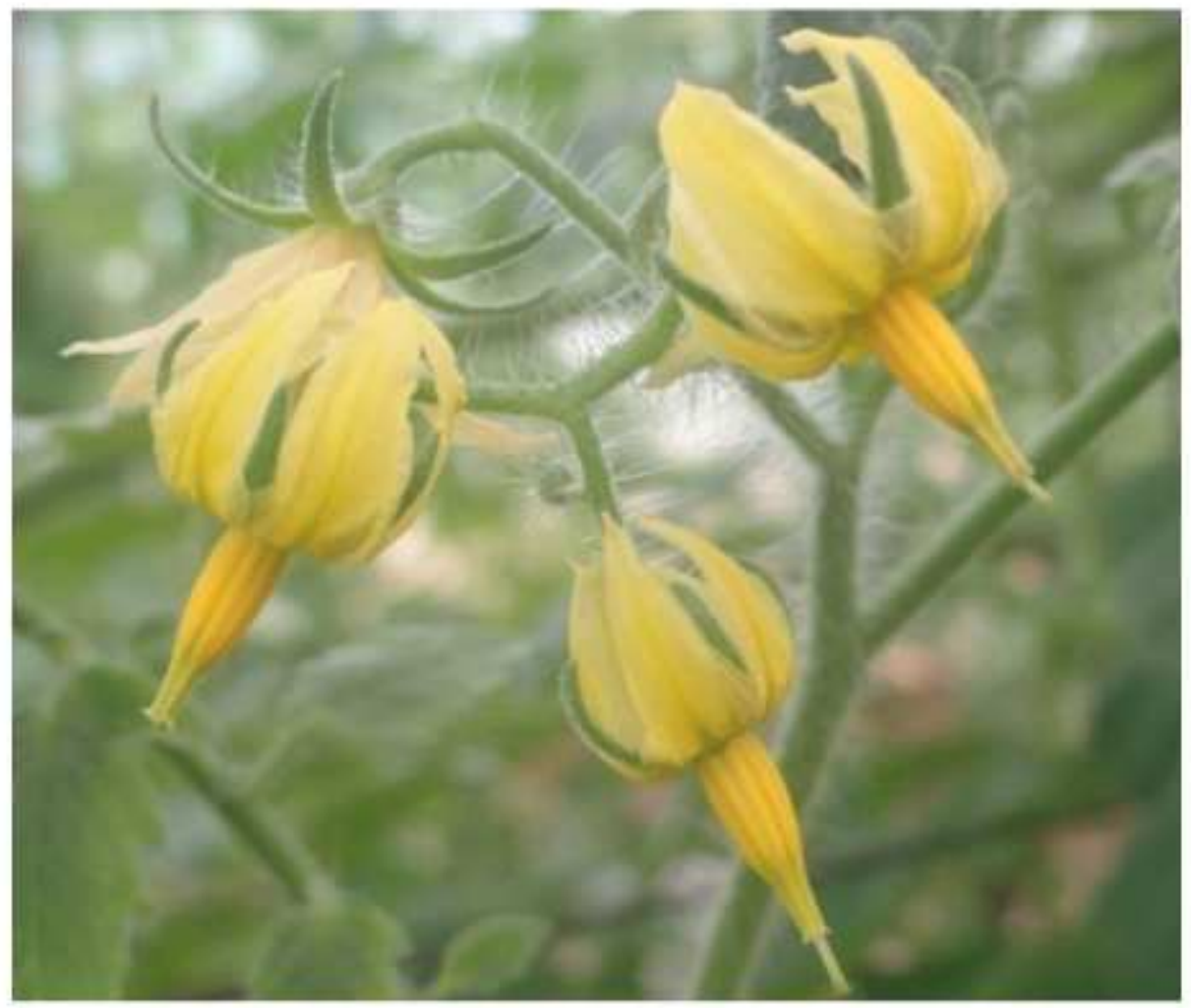

Figure 2

Flowers with introvert and extrovert stigma 


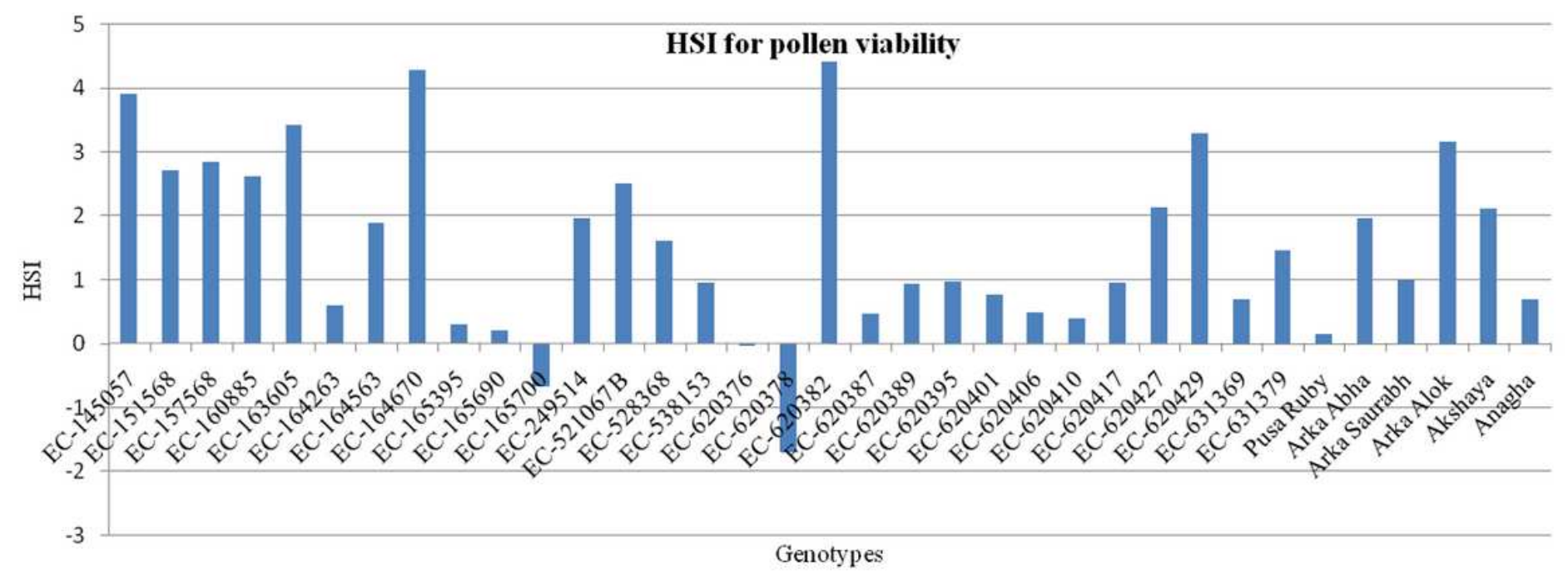

Figure 3

HSI for pollen viability of investigated genotypes

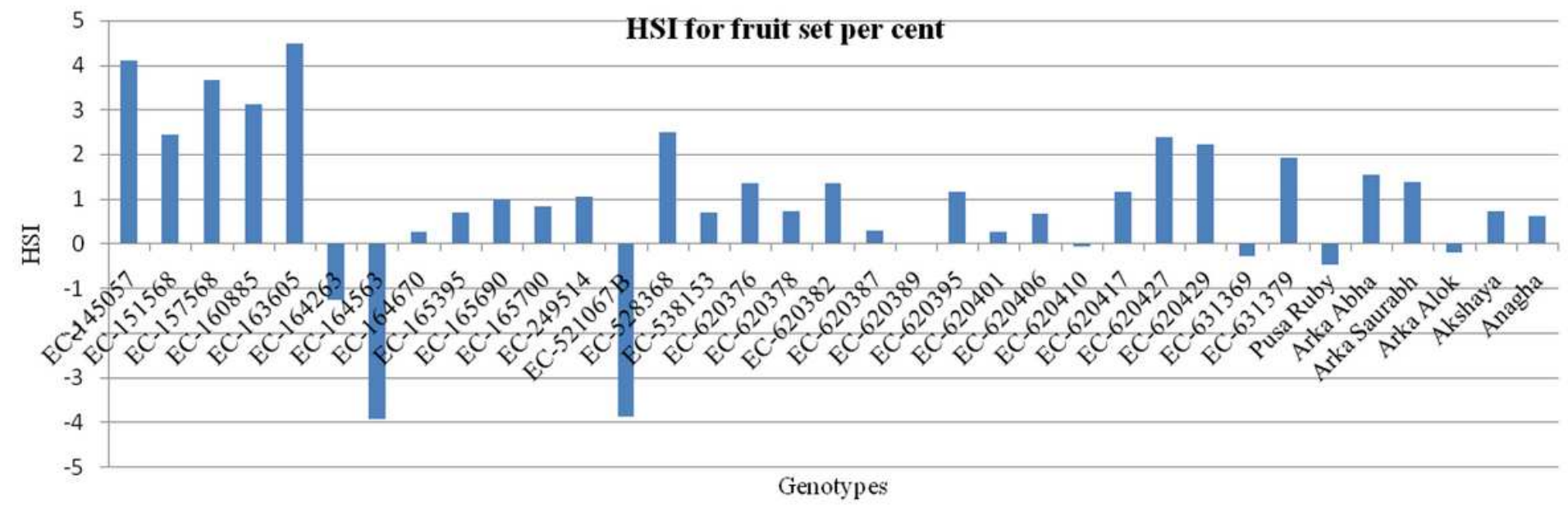

Figure 4

HSI for fruit set per cent of investigated genotypes

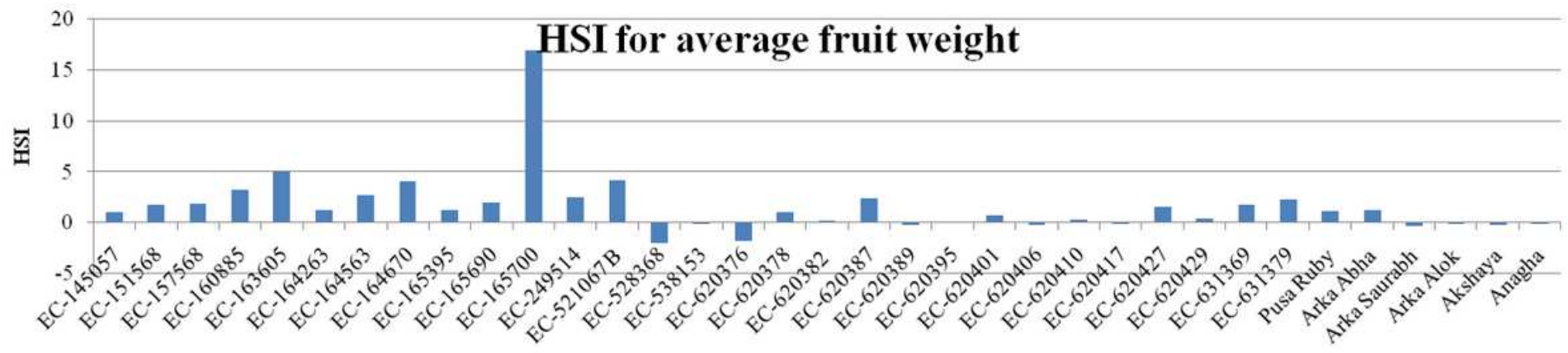

Genotypes

Figure 5 
HSI for average fruit weight of investigated genotypes

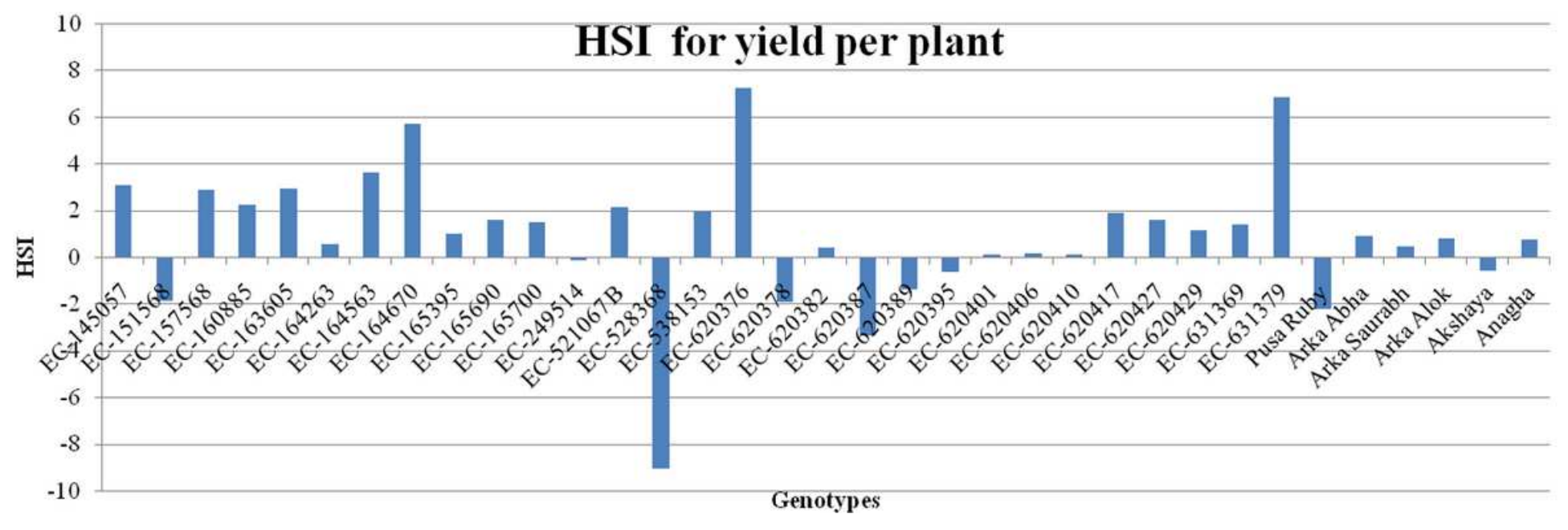

Figure 6

HSI for yield per plant of investigated genotypes 